\title{
FURTHER EVIDENCE OF NORMAL FERTILITY AND THE FORMATION OF BALANCED GAMETES IN SHEEP WITH ONE OR MORE DIFFERENT ROBERTSONIAN TRANSLOCATIONS
}

\author{
A. N. BRUÈRE \\ Department of Veterinary Clinical Science, Massey University, New Zealand
}

(Received 13th Fanuary 1975)

\begin{abstract}
Summary. Mating experiments are described for sheep with three different Robertsonian translocations in the single heterozygous $t_{1}, t_{2}$ and $t_{3}$, homozygous $t_{1} t_{1}$ and $t_{3} t_{3}$ and double heterozygous $t_{1} t_{2}$ and $t_{1} t_{3}$ state. The experiments were designed to investigate several previously reported unusual chromosome segregation ratios in sheep, to test the fertility of translocation heterozygous ewes mated to rams of normal karyotype and to test both the fertility and segregation patterns of sheep which were double translocation heterozygotes.

The fertility of the translocation heterozygous ewes was normal as assessed from conception to first service, numbers of non-conceiving ewes and lambing percentages. Two types of double translocation heterozygous rams mated to ewes of normal karyotype produced regular chromosome segregation patterns in their progeny and the matings were of normal fertility. Double translocation heterozygous ewes were also fertile.

Four sheep were bred with 51 chromosomes. Two of these were triple heterozygotes with three different Robertsonian translocations 51,xy, $t_{1} t_{2} t_{3}$ and $51, x x, t_{1} t_{2} t_{3}$ and two were homozygous for one translocation and heterozygous for the others, namely $51, x^{2}, t_{1} t_{1} t_{3}$ and $51, x x, t_{1} t_{3} t_{3}$. All sheep were phenotypically normal. It is concluded that the $t_{1}, t_{2}$ and $t_{3}$ Robertsonian translocations of sheep do not affect reproductive performance significantly.
\end{abstract}

\section{INTRODUCTION}

The significance of Robertsonian translocations among domestic animals is controversial. In domestic sheep, however, apart from the occasional phenotypic anomaly which may be fortuitously associated with such translocations under specific conditions (Bruère, 1969; Bruère \& Mills, 1971; Bruère et al., 1972; Bruère \& Chapman, 1974), there is little evidence that either the fertility or the effective chromosome segregation patterns of such animals is affected. In cattle, Gustavsson (1969) claimed a reduced fertility of heifers carrying the 1/29 translocation, while Pollock \& Bowman (1974) found no such effect of the 2/4 translocation in the fertility of British Friesian cattle. In man, non- 
disjunction does occur in association with the $\mathrm{D} / \mathrm{G}$ translocation to produce effective trisomy 21 and the translocation mongol, and in tobacco mouse (Mus poschiavinus) crosses aneuploid embryos are formed resulting in a high proportion of embryonic rejection (Gropp et al., 1970; Tettenborn \& Gropp, 1970; Cattanach \& Moseley, 1973).

Recent evidence (Bruère, 1974) from the examination of 660 progeny from 597 ewes showed that the fertility of ewes of normal karyotype $(54, \mathrm{xx})$ was unaffected when mated to either translocation heterozygous $(53, x y, t)$ or translocation homozygous rams $(52, \mathrm{xy}, \mathrm{tt})$. In addition, ten ewes of normal karyotype mated to a double translocation heterozygote produced an above average number of lambs of which 9/10 conceived to first service (Bruère \& Chapman, 1974). This result was limited evidence against the formation of aneuploid spermatozoa leading to unbalanced zygotes and ultimately embryonic rejection as seen in tobacco mouse crosses. The reduced fertility of the $t_{1} \times t_{1}$ matings (Bruère, 1974) suggested that translocation ewes may produce a proportion of aneuploid ova which either are not fertilized or are rejected early in embryogenesis.

To confirm these preliminary observations a further 265 ewes were mated in 1974 and the karyotypes of their 282 progeny studied. All the translocation heterozygous ewes, $53, \mathrm{xx}, \mathrm{t}_{1}, 53, \mathrm{xx}, \mathrm{t}_{2}$ and $53, \mathrm{xx}, \mathrm{t}_{3}$ were mated to rams of normal karyotype $(54, \mathrm{xy})$ in order to test the possibility that they produced a proportion of aneuploid ova which could lead to the formation of aneuploid embryos. In addition, an increased number of ewes of normal karyotype were mated to one of two double translocation heterozygous rams $\left(52, \mathrm{xy}, \mathrm{t}_{1} \mathrm{t}_{2}\right.$ and $\left.52, x y, t_{1} t_{3}\right)$. If the latter were producing aneuploid spermatozoa which were capable of fertilizing, as are such spermatozoa in the tobacco mouse, it would be anticipated that these matings, as would the heterozygous ewe matings, result in a lowered conception to first service, increased numbers of ewes mating but not giving birth to a lamb (dry ewes) and a significantly lowered lambing percentage.

Further observations were also made on the apparently significant deficiency of $53, \mathrm{xx}, \mathrm{t}_{2}$ among the $53, \mathrm{xy}, \mathrm{t}_{2} \times 54, \mathrm{xx}$ matings. In addition, homozygous translocation ewes were mated to a double translocation heterozygous ram $\left(52, \mathrm{xy}, \mathrm{t}_{\mathbf{1}}\right.$ $\left.t_{3}\right)$, and double translocation heterozygous ewes $\left(52, x x, t_{1} t_{3}\right)$ were mated to a translocation homozygous $\mathrm{ram}\left(52, \mathrm{xy}, \mathrm{t}_{2} \mathrm{t}_{2}\right)$. Among the resulting progeny three karyotypically different sheep with 51 chromosomes were produced for the first time.

The results from these matings combined with those of a previous paper (Bruère, 1974) represent segregation and fertility studies on 942 progeny from 862 ewes mated over 6 years.

\section{MATERIALS AND METHODS}

The various karyotype categories, the derivation of the sheep used in this study, the mating and lambing procedure and the method of assessing reproductive performance have been described previously (Bruère, 1974). The control flocks used to make the fertility comparisons for the present series of matings 
were the Massey University stud Romney flock and the Massey University progeny test flock (Romney). Both these flocks were managed on the same farm as the translocation sheep and had similar attention at mating and lambing and were of a similar age composition. Karyotype studies were carried out from routine whole blood cultures for the normal ewes before mating and for the lambs within 1 to 2 weeks of birth. The various mating categories are shown in Tables 1 to 4 .

The G-banding technique used to show the banding differences between translocation $t_{1}$ and $t_{3}$, which are morphologically similar, was a modification of that described by Gallimore \& Richardson (1973). This included a $10 \mathrm{~min}$ denaturation step in $0.07 \mathrm{~N}-\mathrm{NaOH}$ substituted for trypsinization. The $\mathrm{NaOH}$ was followed by incubation for $2 \mathrm{hr}$ at $60^{\circ} \mathrm{C}$ in $2 \times \mathrm{SSC}$ before Giemsa staining. Cells were not banded by this procedure until 6 days after preparation.

Table 1. Numbers and sex of progeny with 54 and 53 chromosomes from mating translocation heterozygous ewes $(53, \mathrm{xx})$ to rams of normal karyotype $(54, \mathrm{xy}):$ (a) $54, \mathrm{xy} \times 53, \mathrm{xx}, \mathrm{t}_{1}$, (b) $54, \mathrm{xy} \times 53, \mathrm{xx}, \mathrm{t}_{2}$ (c) $54, \mathrm{xy} \times 53, \mathrm{xx}, \mathrm{t}_{3}$

\begin{tabular}{lccccc}
\hline \multirow{2}{*}{ Matings } & \multicolumn{5}{c}{ Chromosome number and sex } \\
\cline { 2 - 5 } & $54, \mathrm{xy}$ & $53, \mathrm{xy}, \mathrm{t}$ & $54, \mathrm{xx}$ & $53, \mathrm{xx}, \mathrm{t}$ & \\
\hline (a) $54, \mathrm{xy} \times 53, \mathbf{x x}, \mathrm{t}_{\mathbf{1}}$ & 12 & 16 & 7 & 10 & 45 \\
(b) $54, \mathrm{xy} \times 53, \mathbf{x x} \mathrm{t}_{\mathbf{2}}$ & 7 & 10 & 5 & 9 & 31 \\
(c) $54, \mathrm{xy} \times 53, \mathbf{x x}, \mathrm{t}_{\mathbf{3}}$ & 6 & 10 & $\mathbf{9}$ & 3 & 28 \\
& 25 & 36 & 21 & 22 & $104^{*}$ \\
& & & & & \\
\hline
\end{tabular}

* The pooled data do not differ significantly from the expected ratio of $1: 1: 1: 1$.

\section{RESULTS}

The numbers of translocation and nontranslocation progeny from the mating of the three different types of translocation heterozygous ewes $(53, \mathrm{xx}, \mathrm{t})$ are shown in Table 1 . The data in each category are rather few for detection of minor segregational differences, but overall the expected ratios of progeny were recovered giving a balanced 1:1:1:1 segregation. Further if the data from Table 1(a) are combined with those of Table 2(a) in a preceding paper (Bruère, 1974) and Table 1(b) is combined with Table 2 in this paper the balanced segregation of the translocation chromosomes is apparent. In a preceding paper (Bruère, 1974) a significant and unequal recovery of nontranslocation ewe progeny $(54, \mathrm{xx})$ was noted for the $t_{2}$. However the addition of further data as shown in Table 2(a) and Table 2(b) indicates that this previous difference becomes insignificant in the combined data. It had also been suggested previously that there may have been a segregational association between the $\mathrm{Y}$ chromosome and the $\mathrm{t}_{2}$ chromosome, but the remarkably even recovery of male and female progeny seen in Table 2 clearly negates the earlier result. 
Table 2. Numbers and sex of progeny with 54 and 53 chromosomes from matings of: (a) $53, \mathrm{xy}, \mathrm{t}_{2} \times 54, \mathrm{xx}$, and (b) $54, \mathrm{xy} \times$ $53, \mathrm{xx}, \mathrm{t}_{2}$

\begin{tabular}{|c|c|c|c|c|c|c|}
\hline \multirow{2}{*}{ Matings } & \multirow{2}{*}{ rear } & \multicolumn{4}{|c|}{ Chromosome number and sex } & \multirow{2}{*}{ Total } \\
\hline & & $54, x y$ & $53, \mathrm{xy}, \mathrm{t}_{\mathbf{2}}$ & $54, \mathbf{x x}$ & $53, \mathrm{xx}, \mathrm{t}_{2}$ & \\
\hline \multirow[t]{2}{*}{ (a) $53, \mathrm{xy}, \mathrm{t}_{2} \times 54, \mathrm{xx}$} & $\begin{array}{l}1972^{*} \\
1973 \\
1974\end{array}$ & $\begin{array}{l}16 \\
14 \\
10\end{array}$ & $\begin{array}{l}15 \\
25 \\
14\end{array}$ & $\begin{array}{l}22 \\
16 \\
19\end{array}$ & $\begin{array}{r}9 \\
13 \\
17\end{array}$ & $\begin{array}{l}62 \\
68 \\
60\end{array}$ \\
\hline & Total & 40 & 54 & 57 & 39 & 190 \\
\hline $\begin{array}{l}\text { (b) } 54, \mathrm{xy} \times 53, \mathrm{xx}, \mathrm{t}_{2} \\
\text { (Table 1) }\end{array}$ & 1974 & 7 & 10 & 5 & 9 & 31 \\
\hline (c) Total $(a+b)$ & & 47 & 64 & 62 & 48 & 221 \\
\hline Male versus female & & \multicolumn{2}{|c|}{111} & \multicolumn{2}{|c|}{110} & \\
\hline
\end{tabular}

Tables 3(a) and 3(b) show the segregation patterns for two different types of double translocation heterozygous rams $\left(52, \mathrm{xy}, \mathrm{t}_{1} \mathrm{t}_{2} ; 52, \mathrm{xy}, \mathrm{t}_{1} \mathrm{t}_{3}\right)$ mated to normal ewes $(54, \mathrm{xx})$. Again, a regular segregation pattern is shown among the progeny of each type of double translocation heterozygote but this time a $1: 2: 1$ ratio for normal $(54)$, translocation heterozygotes $(53, t)$ and double translocation heterozygotes $(52, \mathrm{tt})$ respectively. This is particularly evident in the combined data of Tables $3(\mathrm{a})$ and $3(\mathrm{~b})$. Table 4 shows the segregation results of mating a homozygous ram $\left(52, x_{,}, t_{2} t_{2}\right)$ to $53, x x, t_{1}$ ewes. A highly significant excess of $53, \mathrm{xx}, \mathrm{t}$ and a deficiency of $53, \mathrm{xy}, \mathrm{t}$ were recorded from limited data (Bruère, 1974) but the additional breeding data from this series give a further example of how regular is the effective segregation of the translocation chromosomes.

Table 3. Numbers and sex of progeny with 54,53 and 52 chromosomes from matings of: (a) double translocation heterozygous rams $\left(t_{1} t_{2}\right)$ to ewes of normal karyotype, and (b) double translocation heterozygous rams $\left(t_{1} t_{3}\right)$ to ewes of normal karyotype

\begin{tabular}{|c|c|c|c|c|c|c|c|}
\hline \multirow{2}{*}{ Matings } & \multicolumn{6}{|c|}{ Chromosome number and sex } & \multirow{2}{*}{ Total } \\
\hline & $54, x y$ & $54, \mathbf{x x}$ & $53, x y, t$ & $53, \mathrm{xx}, \mathrm{t}$ & $52, x y, t$ & t $52, \mathrm{xx}, \mathrm{t}$ & \\
\hline (a) $52, x y, t_{1} t_{2} \times 54, x x$ & 3 & 5 & 8 & 12 & 9 & 4 & 41 \\
\hline (b) $* 52, x y, t_{1} t_{3} \times 54, x x$ & & ${ }_{15} 8$ & 20 & 29 & 10 & 13 & 57 \\
\hline Total & & 23 & & 49 & & 26 & 98 \\
\hline
\end{tabular}

* Combined data from Bruère \& Chapman (1974) and the 1974 matings.

The reproductive performances of all the different classes of animals mated were equivalent to those expected of the Romney and Drysdale breeds (Tables 5 and 6 ). Conception rates to first service were above the average of $78.8 \%$ recorded for the Romney breed of sheep (Quinlivan \& Martin, 1971). The 
Table 4. Numbers and sex of progeny with

52 and 53 chromosomes from Romney sheep matings $\left(52, x y, t_{2} t_{2} \times 53, x x, t_{1}\right)$

\begin{tabular}{lcccccc}
\hline & \multicolumn{5}{c}{ Chromosome number and sex } & Total \\
\cline { 2 - 6 } & $52, \mathrm{xy}, \mathrm{t}$ & $52, \mathrm{xx}, \mathrm{t}$ & $53, \mathrm{xy}, \mathrm{t}$ & $53, \mathrm{xy}, \mathrm{t}$ & \\
\hline 1973 & 7 & 7 & 1 & 11 & $26^{*}$ \\
1974 & 1 & 0 & 5 & 3 & 9 \\
Total & 8 & 7 & 6 & 14 & $35 \dagger$ \\
\hline
\end{tabular}

$* \chi_{3}^{2}=7.85 ; P<0.05$

$\dagger \chi_{3}^{2}$, not significant.

numbers of dry ewes were no higher than expected and the actual number of lambs born to ewes mated was comparable to the two control flocks of Romney sheep (Table 5d and 5e). The high loss of lambs at birth Tables 5(a) and 6(b) was mainly due to dystocia caused by the heavy lambing condition of the older ewes.

Table 5. Reproductive details of mating translocation Romney $t_{1}$ and $t_{2}$ ewes and Drysdale $t_{3}$ ewes to rams of normal karyotype compared those of the control flocks

\begin{tabular}{|c|c|c|c|c|c|c|}
\hline Mating category & $\mathrm{E}_{\mathrm{M}}$ & $\mathrm{E}_{\mathrm{DM}}$ & $\mathbf{L}_{\mathbf{B M}}$ & $\mathrm{L}_{\mathbf{W M}}$ & $\% \mathrm{E}_{\mathrm{DM}}$ & $\% \mathrm{~L}_{\mathbf{W M}}$ \\
\hline (a) $53, x x, t_{1} \times 54, x y$ & 47 & 3 & 57 & 45 & $6 \cdot 38$ & $95 \cdot 74$ \\
\hline \multicolumn{7}{|c|}{ Conception to first service $83.19 \%$} \\
\hline (b) $53, \mathrm{xx}, \mathrm{t}_{2} \times 54, \mathrm{xy}$ & 25 & 1 & 33 & 32 & $4 \cdot 0$ & $128 \cdot 00$ \\
\hline \multicolumn{7}{|c|}{ Conception to first service $92.0 \%$} \\
\hline (c) $53, \mathrm{xx}, \mathrm{t}_{3} \times 54, \mathrm{xy}$ & 29 & 1 & 32 & 28 & $3 \cdot 45$ & $96 \cdot 55$ \\
\hline \multicolumn{7}{|c|}{ Conception to first service $86 \cdot 12 \%$} \\
\hline Total $(a+b+c)$ & 101 & 5 & 122 & 105 & 4.95 & 103.96 \\
\hline $\begin{array}{l}\text { (d) Progeny test } \\
\text { Romney flock* }\end{array}$ & 244 & 27 & 264 & 231 & $11 \cdot 06$ & $94 \cdot 67$ \\
\hline $\begin{array}{l}\text { (e) Stud Romney* } \\
\text { flock }\end{array}$ & 221 & 13 & 270 & 221 & $5 \cdot 88$ & $100 \cdot 00$ \\
\hline Total ( $d$ and $e)$ & 465 & 40 & 534 & 452 & $8 \cdot 60$ & $97 \cdot 20$ \\
\hline $\begin{array}{l}\mathrm{E}_{\mathrm{M}}=\text { ewes mated } \\
\text { to ewes mated; } \mathrm{L}_{\mathrm{WM}} \\
\text { * Conception rate }\end{array}$ & ewe & ry to & wes 1 & ated & $=$ & s born \\
\hline
\end{tabular}

A double translocation heterozygous $\operatorname{ram}\left(52, \mathrm{xy}, \mathrm{t}_{1} \mathrm{t}_{3}\right)$ was mated to five homozygous ewes $\left(52, \mathrm{xx}, \mathrm{t}_{1} \mathrm{t}_{1}\right)$ and five homozygous ewes $\left(52, \mathrm{xx}, \mathrm{t}_{3} \mathrm{t}_{3}\right)$. Each of these lambed and from the ten ewes thirteen lambs were born. Among the progeny of these ewes were two lambs each with 51 chromosomes. One lamb was homozygous for the $t_{1}$ translocation and heterozygous for the $t_{3}$ 
Table 6. Reproductive details of mating translocation double heterozygous rams: (a) $\left(t_{1} t_{2}\right)$ to ewes of normal karyotype and (b) $\left(t_{1} t_{3}\right)$ rams mated to ewes of normal karyotype

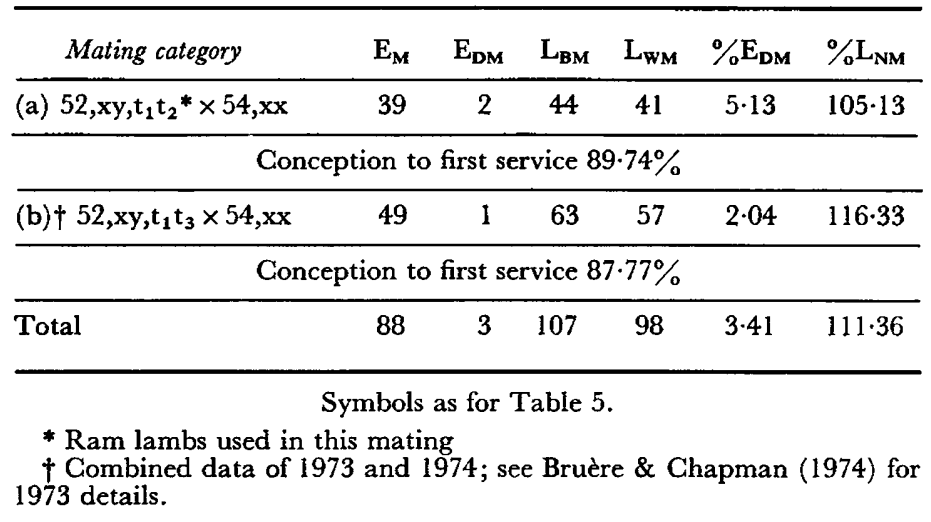

translocation (51, $\left.x x, t_{1} t_{1} t_{3}\right)$ (Pl. 1, Fig. 2), while the other lamb was heterozygous for the $t_{1}$ translocation and homozygous for the $t_{3}$ translocation $(51, x x$, $\mathrm{t}_{1} \mathrm{t}_{3} \mathrm{t}_{3}$ ) (Pl. 2, Fig. 3). Neither lamb was abnormal and both have developed as well as any other lamb in the flock. It is interesting to note however that of the ten homozygous ewes mated, four conceived to their second, rather than their first service. The mating of a homozygous ram $\left(52, x y, t_{2} t_{2}\right)$ to five ewes which were double heterozygotes for the $t_{1}$ and $t_{3}$ translocations resulted in the birth of six lambs. This was again a good reproductive performance, since each ewe was only 18 months of age (a two-tooth) when mated. Among the progeny were two further lambs with 51 chromosomes, a ewe and a ram, both of these were triple heterozygotes and each had all three translocations and were 51, $x x, t_{1} t_{2} t_{3}$ and $51, x y, t_{1} t_{2} t_{3}$, respectively (PI. 2, Fig. 4). Both of these lambs were phenotypically normal and have grown as well as other lambs in the flock. These three categories of sheep with three translocation chromosomes are the only known cases among the domestic animals and man.

\section{DISGUSSION}

These results combined with the results from two previous papers (Bruère, 1974 ; Bruère \& Chapman, 1974) of mating sheep with either one or two Robertsonian translocations to sheep of either normal karyotype or themselves translocation carriers have provided adequate data to conclude that the reproductive performance of such sheep is normal. Further, the remarkably even recovery of all classes of translocation and non-translocation animals shows how regularly their respective gametes are being formed and are participating in fertilization. Although non-disjunction does occur at first meiosis in all three types of translocation heterozygous rams (Chapman \& Bruère, 1975), the unequal products are being eliminated and are not taking part in fertilization. This is evident from two factors; first the exceptionally good rate of conception to first service for all classes of both single and double translocation animals from both the male 


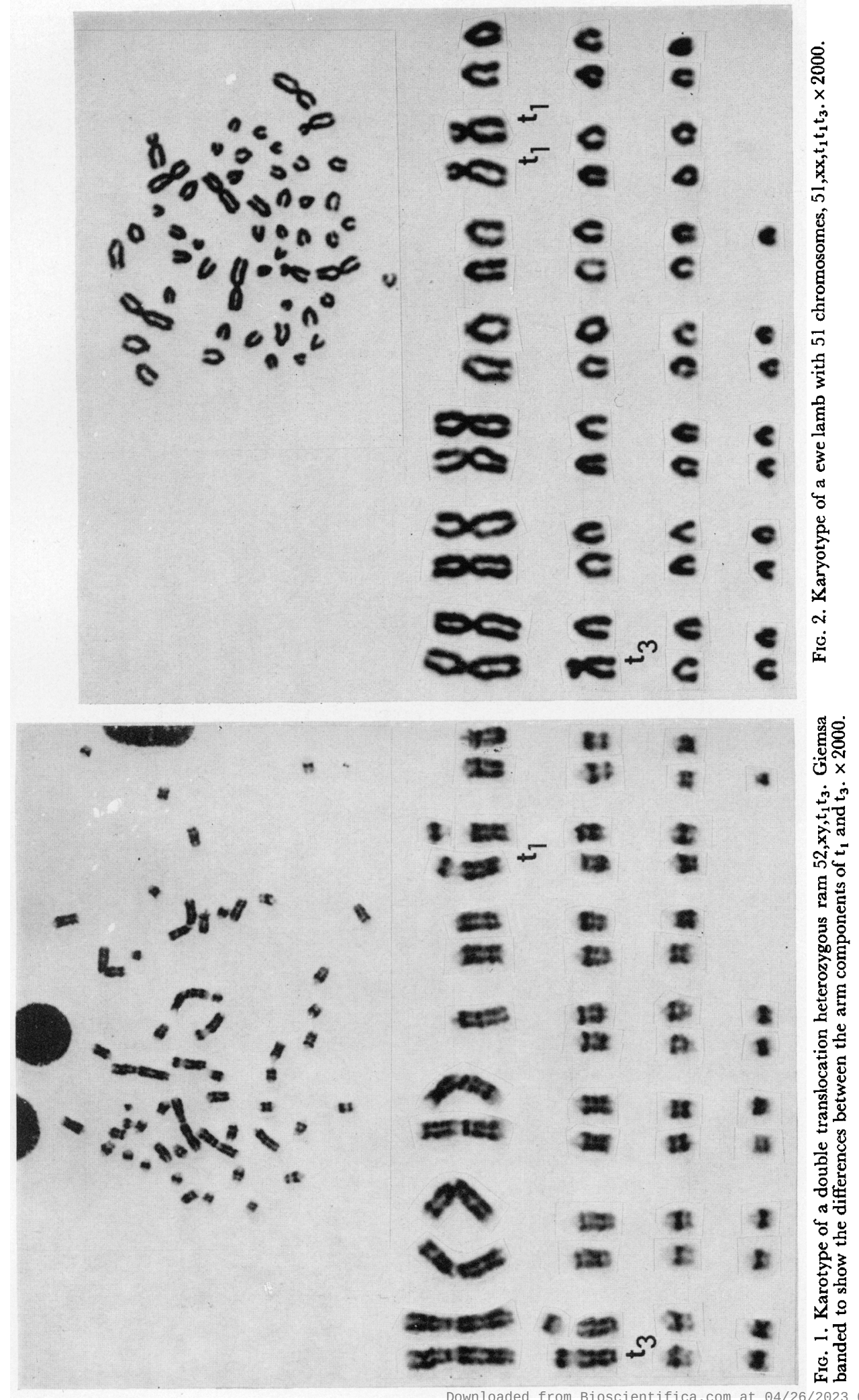


PLATE 2
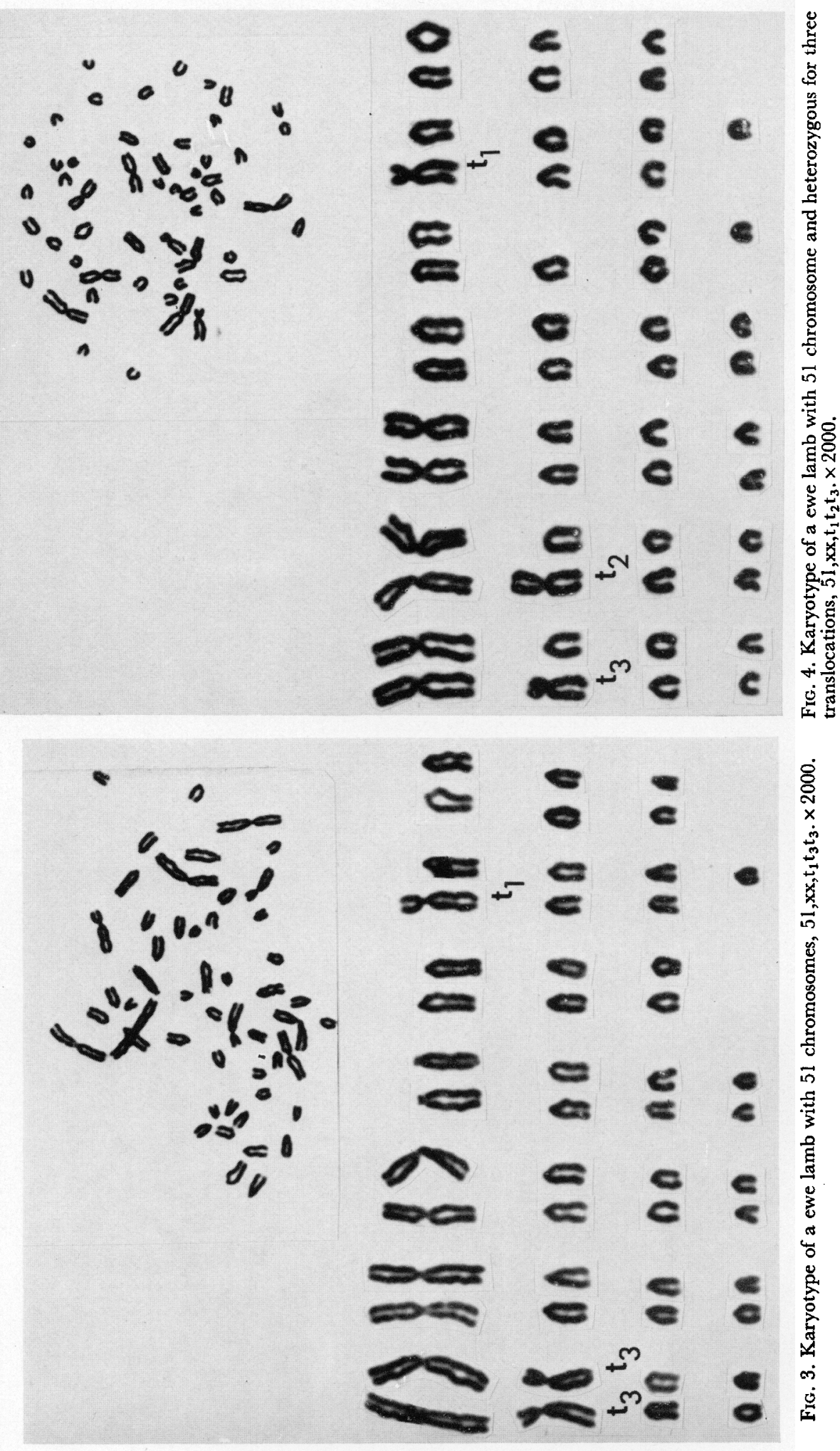
and female sides (Tables 5 and 6; see also Bruère, 1974), and second, the fact that there was no evidence of unbalanced karyotypes from 56,16 to 17 day blastocysts of the $t_{1}$ studied by Long (1974). In addition, the remarkably few dry ewes recorded in nearly all the mating categories in this series of experiments, as well as the absence of any unbalanced karyotype in lambs born either dead or alive, further indicates that extremely few, if any, lambs of unbalanced karyotype were conceived at all. In only one small mating (Bruère, 1974) was an increased number of aborted lambs recorded and this was subsequently confirmed to be due to toxoplasmosis, a common cause of abortion in sheep.

Present information also shows that there is no deleterious effect caused by the presence of one or more translocation chromosomes in any one animal. The only possible evidence of a deleterious effect of two translocation chromosomes is seen in the homozygous animals, in which four of the ten ewes mated returned to service, although the ultimate lambing percentage from these sheep was good. Also noted in 53,xy, $t_{1} t_{1}$ rams have been two cases of 'hourglass' testes (Bruère, 1970). A similar phenomenon was noted in one ram by S. E. Long (personal communication). A tentative explanation of such occasional phenomena has been offered previously in association with Robertsonian translocations in sheep and man (Bruère \& Chapman, 1974).

The results from these extensive studies in sheep are quite different from the only other comparable studies in a mammal, namely the tobacco mouse (Mus poschiavinus). In the tobacco mouse crosses, the presence of seven translocation chromosomes in the heterozygous state leads to the formation of aneuploid gametes which can fertilize, but result in the formation of unbalanced embryos which die (Gropp et al., 1970; Tettenborn \& Gropp, 1970; Cattanach \& Moseley, 1973). The position in the sheep appears the reverse with aneuploid embryos not being formed so that there is no subsequent reduction in fertility. Moreover, comparing the breeding of sheep with Robertsonian translocations to the human D/G translocation, no unbalanced products such as the translocation mongol have been seen. The suspected possibility described in a previous paper (Bruère, 1974), of increased non-disjunction in ewes heterozygous for any one of the three Robertsonian translocations with the formation of aneuploid ova, and resulting in a significantly lowered fertility, was not confirmed in the present results. The translocation heterozygous ewes $\left(53, \mathrm{xx}, \mathrm{t}_{1} ; 53, \mathrm{xx}, \mathrm{t}_{2}\right.$; $53, \mathrm{xx}, \mathrm{t}_{3}$ ) all performed comparably to their reciprocal male matings (Table 5 ). The poor fertility described previously of the $53, \mathrm{xy}, \mathrm{t}_{1} \times 53, \mathrm{xx}, \mathrm{t}_{1}$ and in fact the $53, \mathrm{xy}, \mathrm{t} \times 53, \mathrm{xx}, \mathrm{t}$ in general, can most likely be attributed to the age composition of the flock (Bruère, 1974). Poor conception rates in 18-month-old ewes (two tooths) are not uncommon in grazing sheep in New Zealand (A. L. Rae, personal communication) and the causative factors are probably seasonal.

The incidence of Robertsonian translocations recorded in New Zealand sheep (Bruère \& Mills, 1971; Bruère et al., 1972; Bruère, 1973; A. N. Bruère, unpublished data) is probably high. It is difficult to estimate the overall incidence in the national flock of approximately sixty million sheep, but since the Robertsonian translocations so far reported have been found in major stud Romney and Drysdale flocks at levels of up to $32 \%$ (Bruère et al., 1972), 
it can be concluded that probably several million sheep are translocation carriers. Recently, a translocation has been found in an important Perendale stud flock at a level of $25 \%$ (A. N. Bruère, unpublished data).

Present evidence gives no reason for culling translocation sheep and while the reason for the formation of Robertsonian translocations remains unsolved it can be seen that their effects are quite different between species (Benazzi \& Puccinelli, 1973; Cattanach \& Moseley, 1973; White, 1973; Bruère, 1974). This is particularly emphasized in man in which a limited but medically important effect is seen in the $\mathrm{D} / \mathrm{G}$ mongol. The tobacco mouse is an interesting specimen but the effects of multiple Robertsonian translocations in this species are probably the result of reproductive isolation and as such cannot be extrapolated categorically to other species.

Morphological differences have been described between the centromeric regions of the $t_{1}, t_{2}$ and $t_{3}$ of sheep (Bruère et al., 1974) which suggest that the $t_{2}$, like the $1 / 29$ translocation of cattle, may be a reciprocal translocation, while the $t_{1}$ and $t_{3}$ are dicentric chromosomes, typical of other centric fusion chromosomes in man (Niebuhr, 1972) and cattle (A. N. Bruère, unpublished data). However, these do not appear to produce any differences in either the segregation patterns or the fertility of the sheep concerned.

Although occasional phenotypic anomalies have been found associated with Robertsonian translocations in sheep (Bruère, 1969; Bruère \& Mills, 1971; Bruère et al., 1972), and an explanation for these has been suggested (Bruère \& Chapman, 1974), it can be concluded that Robertsonian translocations appear to play a neutral role in reproduction of sheep. Their exact genetic significance is not yet apparent.

\section{ACKNOWLEDGMENTS}

This work was supported by a grant from the Wellcome Trust of Great Britain. The author gratefully acknowledges the assistance of Professor A. L. Rae and Mr P. H. Whitehead and Mr W. M. Deighton of the Sheep Husbandry Department. The expert technical assistance of Miss Priscilla Jaine is particularly acknowledged and again I am grateful for the continued assistance of Mrs $\mathrm{B}$. Bruère and $\mathrm{Mr}$ Richard, Mr Stuart and Mr Andrew Bruère. The author also wishes to thank Dr D. L. Zartman for his assistance in developing the G-banding technique in this laboratory. Mrs J. Pearce typed the manuscript.

\section{REFERENCES}

Benazzi, M. \& Puccinelir, I. (1973) A Robertsonian translocation in the fresh-water triclad Dugesia lugubris: karyometric analysis and evolutionary inferences. Chromosoma 40, 193-198.

BRUk̇RE, A.N. (1969) Male sterility and an autosomal translocation in Romney sheep. Cytogenetics 8, 209-218.

BRUÈre, A.N. (1970) Some clinical aspects of hypo-orchidism (small testes) in the ram. N.Z. vet. $\mathcal{F}$. 18, 189-198.

Brù̀re, A.N. (1973) Population studies on a further familial translocation of sheep. Vet. Rec. 92, 319321.

BRUÈrE, A.N. (1974) The segregation patterns and fertility of sheep heterozygous and homozygous for three different Robertsonian translocations. F. Reprod. Fert. 41, 453-464. 
BruĖre, A.N. \& ChapmaN, H.M. (1974) Double translocation heterozygosity and normal fertility in domestic sheep. Cytogenet. Cell Genet. 13, 342-351.

Bruère, A.N. \& Mills, R.A. (1971) Observations on the incidence of Robertsonian translocations and associated testicular changes in a flock of New Zealand Romney sheep. Cytogenetics 10, $260-272$.

Brutere, A.N., Chapman, H.M. \& Wyllie, D.R. (1972) Chromosome polymorphism and its possible implications in the select Drysdale breed of sheep. Cytogenetics 11, 233-246.

Bruère, A.N., Zartman, D.L. \& Chapman, H.M. (1974) The significance of the G-bands and G-bands on three different Robertsonian translocations of domestic sheep (Ovis aries). Cytogenet. Cell Genet. 13, 479-488.

Cattanach, B.M. \& Moseley, H. (1973) Nondisjunction and reduced fertility caused by the tobacco mouse metacentric chromosomes. Cytogenet. Cell Genet. 12, 264-287.

Chapman, H.M. \& BRUìre, A.N. (1975) The frequency of aneuploidy in the secondary spermatocytes of normal and Robertsonian translocation-carrying rams. F. Reprod. Fert. 45, 333-342.

Gallimore, P.H. \& Richardson, G.R. (1973) An improved banding technique exemplified in the karyotype analysis of two strains of rat. Chromosoma 41, 259-263.

Gropp, A., Tettenborn, U. \& Lehmann, E. von (1970) Chromosomenvariation vom Robertson' schem Typus bei der Tabakmaus, $M$. poschiavinus, und ihren Hybriden mit der Laboratoriumsmaus. Cytogenetics 9, 9-23.

Gustavsson, I. (1969) Cytogenetics, distribution and phenotypic effects of a translocation in Swedish cattle. Hereditas 63, 68-169.

Long, S.E. (1974) Fertility of sheep with a Robertsonian translocation. Vet. Rec. 94, 161.

NiebuHr, E. (1972) Dicentric and monocentric Robertsonian translocations in man. Humangenetik $16,217-226$.

Pollock, D.L. \& Bowman, J.C. (1974) A Robertsonian translocation in British Friesian cattle. $\mathcal{F}$. Reprod. Fert. 40, 423-432.

Quinlivan, T.D. \& MARTin, G.A. (1971) Survey observations on the reproductive performance of both Romney stud and commercial flocks throughout New Zealand. I. National Romney stud performance. $\mathcal{N}$.Z. F. agric. Res. 14, 417-433.

Tettenborn, U. \& Gropp, A. (1970) Meiotic nondisjunction in mice and mouse hybrids. Cytogenetics 9, 272-283.

WhITE, M.J.D. (1973) Animal Cytology and Evolution, 3rd edn. Cambridge University Press. 